УДК [811. 161. 1:811. 131.1]'38

ББК 81.00

DOI: https://doi.org/10.17308/lic. 2020.3/2941

\title{
ГЛАГОЛЫ РЕЧИ И МЫСЛИ КАК СРЕДСТВА СВЯЗИ В ИТАЛЬЯНСКОМ ТЕКСТЕ
}

\author{
P. А. Говорухо \\ Российский государственный гуманитарный университет
}

\section{VERBS OF SPEAKING AND THINKING AS LINKING ELEMENTS IN ITALIAN TEXT}

\author{
R. A. Govorukho \\ Russian State University for the Humanities
}

\begin{abstract}
Аннотация: в статье анализируются итальянские и русские глаголь мысли и речи, материалом для исследования послужили около 400 примеров, собранных в ходе анализа оригинальных художественных текстов на двух языках и их переводов. Основная задача состоит в том, чтобы выделить те элементы итальянского текста, которые с точки зрения русского языкового сознания могут показаться лишними, и определить их функиию в тексте. При рассмотрении глаголов речи особое внимание уделено конструкичиям с прямой речью, а также интерпретационным глаголам типа 'mеntire' и 'insistere', в которых отмечаются разные способы заполнения валентности содержания при присоединении пропозиционального актанта. Также рассматриваются глаголь-эмотивы, которые часто употребляются с дополнительным предикатом ментальной семантики. Новизна работы видится в том, что впервые определяются контексты употребления таких предикатов, исследуется степень их обязательности/факультативности, причины включения в структуру высказывания. Делается вывод, что в иелом элементы модуса получают в итальянском тексте более развернутое выражение по сравнению с русским текстом, где наблюдается тенденция к их полной или частичной редукции, что указывает на сущуествование разных стратегий концептуализации и языкового кодирования элементов когнитивной структуры в двух языках. Сделанные выводы имеют несомненную практическую значимость, поскольку анализируемые в работе явления относятся к области коллективного языкового узуса, знание которого помогает говорящему на иностранном языке избежать интерференции с родным языком.
\end{abstract}

Ключевые слова: пропозициональные глагольl, глаголь речи и мысли, связность текста, итальянский текст, русский текст.

\begin{abstract}
Italian and Russian verbs of thinking and speaking using approximately 400 examples that were collected during the study of original fiction texts in the two languages and their translations. The main goal is to identify the elements of Italian text that may seem superfluous to a Russian speaker and to determine their textual function. In the case of verbs of speaking, we focus on constructions using direct speech and on interpretative verbs such as 'mentire' and 'insistere' that have different ways of generating content valence with a propositional actant. We also examine emotive verbs that are often used with a supplementary predicate of mental semantics. The novelty of the research lies in the fact that it tries for the first time to define the contexts of use of such predicates and to study their degree of obligatoriness/optionality and the reasons for their inclusion in a phrase. We show that the elements of this mode are, on the whole, more fully expressed in the Italian text than in the Russian text, where they tend to be completely or partially reduced, pointing to the existence of different strategies of conceptualizing and linguistically coding elements of cognitive structure in the two languages. The conclusions have clear practical significance, as the studied phenomena relate to the domain of collective language use, whose knowledge will help foreign speakers to avoid interference with their native language.

Key words: propositional verbs, verbs of speaking and thinking, textual coherence, Italian text, Russian text.
\end{abstract}

(C) Говорухо Р. А., 2020

(i) Контент доступен под лицензией Creative Commons Attribution 4.0 License.

The content is available under Creative Commons Attribution 4.0 License. 


\section{Вводные замечания}

Данная работа является продолжением серии сопоставительных исследований предикатов, присоединяющих сентенциальный актант в итальянском и русском языках [1-3].

Языковые явления, находящиеся в фокусе нашего внимания, относятся к коллективному речевому узусу, под которым понимается естественное употребление слова или выражения, связанное с выбором наиболее адекватной единицы из множества возможных синонимичных языковых средств. Частотный, регулярно воспроизводимый говорящими выбор той или иной языковой единицы или конструкции непосредственно связан с грамматикой, если понимать грамматическое значение как «пучок свойств, а границу между грамматическим и неграмматическим рассматривать как градуальную» [4, с. 19]. Подход к грамматике как к системе, управляющей языковыми выборами, в последние годы все больше утверждается в лингвистике. В новейшем грамматическом описании итальянского языка Микеле Пранди и Кристины Де Сантис, наряду с традиционной «грамматикой правил» (una grammatica delle regole), также описывается «грамматика выбора» (una grammatica delle scelte), которая выражается на уровне сложного предложения и текста [5, pp. XXXI-XXXIV].

Правила, связанные с «грамматикой выбора», не совпадают в разных языках. Важным источником их контрастивного анализа является двусторонний перевод, в том числе литературный, который можно рассматривать как особый случай межъязыкового перифразирования. Некоторые обязательные трансформации при переводе позволяют делать выводы о системных различиях между языками. Трансформации, связанные с «грамматикой выбора», описать сложнее, поскольку литературный перевод всегда подвержен влиянию личности переводчика и его языковому выбору, а потому установленные соответствия могут включать долю лингвистической субъективности. В то же время сходный выбор разных переводчиков при двустороннем (русско-итальянском и итальянско-русском) переводе можно рассматривать как проявление коллективного речевого узуса, который в конечном итоге связан с особенностями языковой системы.

Основным материалом исследования были двусторонние литературные переводы, привлекались также материалы итальянско-русского подкорпуса Национального корпуса русского языка (НКРЯ). Всего было проанализировано около 400 примеров.

К предикатам, присоединяющим сентенциальный актант, прежде всего принадлежат три группы предикатов, непосредственно связанные с «разумной» природой человека [6, с. 428-437]. Они выражают суждение субъекта о ситуации (предикаты знания и мнения), эмоциональную оценку ситуации (эмотивы), а также волю субъекта (предикаты желания и необходимости). Кроме того, к предикатам пропозициональной установки относят глаголы речи, характеризующие человека как активного деятеля, а также глаголы восприятия, которые характеризуют человека как живое существо, обладающее разумом, поскольку восприятие включает когнитивную интерпретацию данных перцепции.

Ниже мы подробно остановимся на тех случаях, когда для построения правильного текста в итальянском языке требуется присутствие дополнительного глагола пропозициональной установки.

\section{Глагол пропозициональной установки в конструкциях с прямой речью}

В работе [1] рассматривались конструкции с глаголами речи, был проведен их семантический анализ, проанализирована роль в контекстах побуждения, когда в русском тексте присутствует частица пусть/ пускай, показаны корреляции глаголов речи и мысли, прежде всего - в конструкциях внутренней речи, сделан вывод о меньшей частотности глаголов говорения в русском тексте.

Сходные наблюдения могут быть сделаны и относительно конструкций с прямой речью, на которых мы остановимся подробнее. Прямая речь представляет собой независимое в синтаксическом отношении и самодостаточное в смысловом отношении высказывание. Соответственно, позиция глагола речи во вводной клаузе не является обязательной при прямой речи и в обоих языках может остаться незамещенной. В русском тексте компрессия предикатов речи наблюдается несколько чаще, прямая речь может непосредственно следовать за глаголами акциональной семантики или предшествовать им, что не характерно для итальянского текста. Из 76 переводов на русский в 52 случаях (68 \%) глагол речи отсутствует. При переводе на итальянский из 68 примеров глагол речи добавлен в 32 случаях (47 \%). Отметим, что подобное отсутствие verba dicendi возможно, прежде всего, в письменной русской речи. Ср.:

\begin{tabular}{|c|c|}
\hline $\begin{array}{l}\text { 1. [Il nonno si mosse e stava } \\
\text { per cadere. La mamma gridò.] } \\
\text { Allora il vigile si avvicinò a } \\
\text { noi e chiese: - Lo conoscete? } \\
\text { (Nanetti). }\end{array}$ & 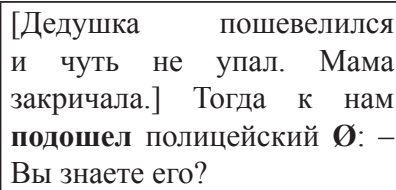 \\
\hline $\begin{array}{l}\text { 2. "Vengo io, vengo io" dis- } \\
\text { se subito Stefano e si alzo } \\
\text { con precipitazione. (Buzzati, } \\
\text { НКРЯ). }\end{array}$ & $\begin{array}{l}- \text { Иду, иду! - Стефано } \\
\text { мгновенно вскочил на ноги. }\end{array}$ \\
\hline $\begin{array}{l}\text { 3. Non l'abbiamo visto affat- } \\
\text { to, non è vero, Adso?» disse } \\
\text { Guglielmo volgendosi verso di } \\
\text { me... (Eco, НКРЯ). }\end{array}$ & $\begin{array}{l}\text { «А мы его не видели, вер- } \\
\text { но, Адсон?» - Вильгельм } \\
\text { повернулся ко мне с лукавой } \\
\text { усмешкой. }\end{array}$ \\
\hline
\end{tabular}

1. [Il nonno si mosse e stava [Дедушка пошевелился per cadere. La mamma gridò.] и чуть не упал. Мама Allora il vigile si avvicinò а закричала.] Тогда к нам noi e chiese: - Lo conoscete? подошел полицейский Ø: Вы знаете его?

se subito Stefano e si alzò мгновенно вскочил на ноги. con precipitazione. (Buzzati, НКРЯ).

to, non è vero, Adso?» disse но, Адсон?» - Вильгельм me... (Есо, НКРЯ). 


\begin{tabular}{|l|l|}
\hline $\begin{array}{l}\text { 4. - Ну будет, будет! - Зуров } \\
\text { отобрал у него пистолет } \\
\text { и хлопнул его по плечу } \\
\text { (Акунин). }\end{array}$ & $\begin{array}{l}\text { Zurov togliendogli di mano la } \\
\text { rivoltella e dandogli una pacca } \\
\text { sulla spalla. }\end{array}$ \\
\hline $\begin{array}{l}\text { 5. Ты что? - Танабай под- } \\
\text { скочил к нему... (Айтматов, }\end{array}$ & $\begin{array}{l}\text { - Cos'hai - disse Tanabaj av- } \\
\text { vicinandosi... }\end{array}$ \\
НКРЯ). & \\
\hline
\end{tabular}

Характерно, что в последних трех примерах в итальянском тексте, где представлены обе предикации, активное действие кодируется формой герундия и имеет статус сопутствующей информации, тогда как в роли основной предикации выступает глагол речи.

Интересны случаи, когда в русском тексте функцию комментирующего глагола речи выполняет именная группа предикативной семантики, а в итальянском к этому добавляется глагол пропозициональной установки. Ср.:

\begin{tabular}{|c|c|}
\hline $\begin{array}{l}\text { 6. ...Fece, come sempre all'ora } \\
\text { dei pasti, il macabro scherzo } \\
\text { di dire: "Il pranzo è servito" } \\
\text { (Campanile). }\end{array}$ & $\begin{array}{l}\text {...Выдал, как это всегда } \\
\text { бывало в часы приема пищи, } \\
\text { мрачную шутку Ø:- Кушать } \\
\text { подано. }\end{array}$ \\
\hline $\begin{array}{l}\text { 7. C'è il disegnino dell'orolo- } \\
\text { gio con la didascalia che dice: } \\
\text { stanotte ricordatevi di mettere } \\
\text { le lancette un'ora avanti... } \\
\text { (Piccolo). }\end{array}$ & $\begin{array}{l}\text { Появляется рисунок часов } \\
\text { с подписью над ним Ø: } \\
\text { не забудьте сегодня ночью } \\
\text { перевести стрелки на час } \\
\text { вперед... }\end{array}$ \\
\hline $\begin{array}{l}\text { 8. Голос показался тоже } \\
\text { не чужим Ø: }- \text { Не уходите } \\
\text { (Евтушенко). }\end{array}$ & $\begin{array}{l}\text { Né le risuonò estranea la voce } \\
\text { che proferì: - Non andate via. }\end{array}$ \\
\hline $\begin{array}{l}\text { 9. Есть такая английская } \\
\text { пословица - «у каждого в } \\
\text { шкафу спрятан свой скелет» } \\
\text { (Пелевин). }\end{array}$ & $\begin{array}{l}\text { C'è un proverbio inglese che } \\
\text { dice: "Ognuno ha il suo sche- } \\
\text { letro nell'armadio". }\end{array}$ \\
\hline
\end{tabular}

В последнем примере очевидно, что актуализатор такой с отсылочным катафорическим значением усиливает когезию русского текста и является прямым аналогом итальянского глагола речи.

\section{Пропозициональный актант при некоторых глаголах речи}

Появление предикатов дополнительного речевого модуса в итальянском тексте может определяться валентностью глаголов говорения, т. е. быть фактом словаря. Так, например, итальянский глагол mentire 'лгать', 'врать' отличается от своих русских аналогов способами заполнения валентности содержания и имеет ограничения при присоединении пропозиционального актанта. Ср.:

\begin{tabular}{|c|c|}
\hline $\begin{array}{l}\text { 10. Самый удобный способ } \\
\text { отказа - это соврать Ø, что } \\
\text { денег нет (Хармс). }\end{array}$ & $\begin{array}{l}\text { Il sistema più comodo di ri- } \\
\text { fiutare è quello di mentire, di } \\
\text { dire che non si hanno soldi. }\end{array}$ \\
\hline
\end{tabular}

\begin{tabular}{|c|c|}
\hline $\begin{array}{l}\text { 11. Дарьюшка потихоньку } \\
\text { продает старые платья и } \\
\text { книги и лжет хозяйке Ø, } \\
\text { что скоро доктор получит } \\
\text { очень много денег (Чехов, } \\
\text { НКРЯ). }\end{array}$ & $\begin{array}{l}\text { Dàr'juška di nascosto vende- } \\
\text { va dei vecchi vestiti e dei li- } \\
\text { bri e mentiva con la padrona } \\
\text { dicendo che presto il dottore } \\
\text { avrebbe ricevuto moltissimo } \\
\text { denaro. }\end{array}$ \\
\hline $\begin{array}{l}\text { 12. И тогда уже мы и до- } \\
\text { строим их башню, ибо до- } \\
\text { строит тот, кто накормит, } \\
\text { а накормим лишь мы... и } \\
\text { солжем Ø, что во имя твое } \\
\text { (Достоевский, НКРЯ). }\end{array}$ & $\begin{array}{l}\text { Saremo noi, allora, a portare } \\
\text { a termine la costruzione della } \\
\text { loro torre giacché potrà ulti- } \\
\text { marla chi darà loro da man- } \\
\text { giare, e soltanto noi li sfame- } \\
\text { remo... e mentiremo dicendo } \\
\text { che lo facciamo nel tuo nome. }\end{array}$ \\
\hline
\end{tabular}

Ю. Д. Апресян относит «врать» к лексико-семантическому классу интерпретационных глаголов, которые «сами по себе не обозначают никакого конкретного действия, а служат лишь для оценочной интерпретации другого, вполне конкретного действия, не обязательно физического, представляемого как уже совершенное кем-то» [7, с. 503].

Еще одним глаголом, включающим смысловой компонент 'говорение', который может эксплицироваться в итальянском тексте, является глагол insistere 'настаивать'. Ср.:

13. [...] Io ho un appuntamento [...] У меня здесь встреча с con un certo signor Anselmi... господином Ансельми, коche lei insiste nel dire di non торый, как вы утверждаете conoscere... (Lunari). $\quad$ Ø, вам не известен.

14. Он настаивал на том, Egli insisteva sempre nel dire что русский мужик есть сви- che il contadino russo è un нья и любит свинство (Тол- porco, che ama la sporcizia... стой, НКРЯ).

На то, что глаголы mentire (лгать, врать) и insistere (настаивать) являются глаголами речевого действия и включают сему 'говорение', указывают и их словарные определения:

Insistere - 'Continuare con ostinazione o petulanza a dire o a fare q.c.' [8, p. 957].

Mentire - 'Dire il falso, il contrario di quello che si pensa esser vero' $[8$, p. 1138].

При этом лишь глагол insistere является в итальянском языке глаголом пропозициональной установки. Cр.: Insiste che non ha mai conosciuto questa persona. Ho: *Mente che non ha mai conosciuto questa persona.

Согласно данным наиболее полного словаря глагольного управления Blumenthal - Rovere, в котором учтены также данные разговорного итальянского языка, конструкции типа N-V-di inf и N-V-che S c глаголом mentire являются в современном итальянском языке редкими.

Mentì di essere il fratello della vittima. Mentì che gli avevano rubato il portafoglio [9, p. 674].

В качестве пропозиционального актанта mentire может присоединять только номинализованный дик- 
тум в рамках конструкции с предлогом N-V-prep N1: mentire sulla indisponibilità di denaro. Cp.:

I brasiliani hanno mentito per anni sulle reali condizioni della loro produzione di caffè [9, p. 675].

Отметим, что аномальность конструкции «mente che...» является, по-видимому, речевой нормой современного литературного языка. Двенадцать опрошенных информантов (люди с высшим и неоконченным высшим образованием из разных, в основном из северных и центральных, областей Италии) считают такую конструкцию неправильной. В то же время в «Синтаксисе итальянского языка» Паоло Гарильяно, изданном в 2002 г. в г. Катания (Сицилия), употребление глагола mentire иллюстрируется целой серией авторских примеров с пропозициональным актантом: Mentii che lo avessi / avevo aiutato. Mentiscono che hanno ricevuto dei regali... и т. д. [10, р. 267]. Хотя научность и обоснованность данного издания вызывает большие сомнения, его, на наш взгляд, следует учесть хотя бы как иллюстрацию диатопической вариативности, существующей в современном итальянском языке, в том числе и в области синтаксической нормы. Возможно, в данном случае речь идет о региональном варианте итальянского языка.

Представляется, что разные способы заполнения валентности содержания при присоединении пропозиционального актанта связаны с семантикой глаголов mentire и insistere. Пресуппозитивная часть их значения, указывающая на конкретное речевое действие, как раз и эксплицируется в итальянском тексте, выполняя роль элемента связи. При этом усиление прагматических факторов в случаях оценочной и субъективной интерпретации сопровождается ослаблением коммуникативной значимости диктального содержания, которое отступает на второй план и редуцируется.

Оба глагола, включающие составляющую 'речевое действие’ (ср. перформативное употребление глагола 'настаивать' [11, с. 201]), могут присоединять слабое зависимое в виде обстоятельства цели, причем insistere выступает в этом случае в роли полувспомогательного модального глагола, семантическая составляющая которого может легко опускаться в переводе:

\begin{tabular}{|l|l|}
\hline 15. Dei regali che Luca le ave- & Из всех подарков, которые \\
va fatto, Lisa aveva insistito & ей сделал Лука, один Лиза Ø \\
per restituirgliene uno... (Lo- & вернула ему обратно. \\
doli).
\end{tabular}

В отличие от глагола mentire, для глагола insistere словарь управления Blumenthal P., Rovere G. фиксирует возможность подчиненной предикации N-V-che $\mathrm{S}$ : A questo riguardo torniamo a insistere che non si può parlare di sistema... [9, pp. 596-597].
В то же время, подобно глаголу mentire, insistere не может присоединять прямое дополнение N1: Insisto nella mia opinione, nelle mie affermazioni. Хaрактерно, что пример словаря, иллюстрирующий управление с помощью предлога $i n$, также включает глагол речи dire в качестве строевого элемента при вводе подчиненной предикации: Sono numerose le pagine in cui l'autore insiste nel dire che la libertà economica non deve essere sfrenata, o senza limiti [9, p. 596].

Таким образом, модус говорения присутствует в итальянском тексте в большей степени в конструкциях как с прямой, так и косвенной речью. В ряде случаев это обусловлено семантикой конкретных глаголов.

\section{Эмотивы с пропозициональным актантом}

В работе [2], посвященной анализу конструкций с глаголами знания и мнения, указывается на связь субъекта эпистемической оценки с субъектом эмоционального состояния. В частности, рассматриваются модусы типа удивительно, любопьтно, интересно, объединяющие значения как ментального, так и эмоционального планов. При этом возможный вопрос, следующий за эмоциональной реакцией, в итальянском тексте может вводиться с помощью глагола пропозициональной установки sapere. Ср.:

16. Интересно, а где вы толь- Sono curiosa di sapere dove è ко что были? (Гришковец).

Продолжая эту мысль, подчеркнем, что эмоциональные состояния и реакции развиваются на когнитивной основе, которая в свою очередь закладывается в процессе непосредственного восприятия окружающего мира и его осмысления, реализуя модель: Si stupi vedendo / sapendo ... = perché aveva visto / saputo.

«Экспериенциальное состояние - принципиально двухместное, т. е. это всегда отношение - отношение человека к ситуации внешнего мира» [12, c. 213]. Итальянский текст, как правило, «реагирует» на это, эксплицитно указывая на канал восприятия внешнего мира как источник эмоционального состояния. Ср.:

17. Non si stupì di vedere, a Его вовсе не удивило Ø, что cavalcioni del davanzale, il so- на подоконнике сидел прежlito ragazzino che, immobile, ний мальчик и смотрел на guardava il mare (Baricco). $\quad$ море.

18. ...Он с радостью предложил свою помощь... нетерпеливо любопьтствуя,

Ø что там за дача (Трифонов).
..Aveva offerto con gioia il suo aiuto ...curiosissimo di vedere la famosa dacia.. 


\begin{tabular}{|c|c|}
\hline 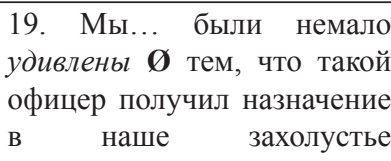 & $\begin{array}{l}\text {...Fummo sorpresi non poco } \\
\text { di vedere che un ufficiale di } \\
\text { tale levatura fosse stato inviato } \\
\text { nello sperduto paese in cui ci }\end{array}$ \\
\hline (Гаврилов). & trovavamo. \\
\hline
\end{tabular}

Если в первом примере глагол vedere описывает ситуацию непосредственного осуществленного визуального контакта, а во втором - этот контакт является желательным, то в последнем случае vedere уже можно считать глаголом пропозиционального отношения, актуализирующим свое широкое эпистемическое значение.

Для итальянского текста в большей мере характерно употребление эмотивных предикатов в первичной для них позиции сказуемого главного предложения при причинном придаточном, сказуемым в котором выступает сенсорный предикат. Ср.:

\begin{tabular}{|l|lrr|}
\hline $\begin{array}{l}\text { 20. Provai un senso di ostilità } \\
\text { vedendo quelle signore inutili }\end{array}$ & Я & вдруг & почувствовал \\
e vive... (Camon). & $\begin{array}{l}\text { но накость к этим живым, } \\
\text { светским дамам... }\end{array}$ \\
\hline
\end{tabular}

В качестве дополнительных модализаторов в итальянском тексте не случайно выступают предикаты с перцептивной, а также с ментальной семантикой. Перцепция каузируется состоянием мира, на основе перцепции возникают психические реакции, а эмоции субъекта связаны с мыслью об объекте. Значение пропозиционального отношения, таким образом непосредственно связано именно с эпистемическим модусом [6, с. 414], и потому все эмотивы, способные присоединять пропозициональный актант, актуализируют ментальный компонент своего значения: «участник Содержание получает соответствующее синтаксическое оформление - союзом что» [13, c. 285]. Сp.:

\begin{tabular}{|l|l|}
\hline $\begin{array}{l}\text { 21. ...Мне вдруг стало } \\
\text { страшно Ø, что она не } \\
\text { приедет... (Казаков). }\end{array}$ & $\begin{array}{l}\text {..D'un tratto mi prese l'an- } \\
\text { goscia } \text { al pensiero che lei non } \\
\text { arrivasse... }\end{array}$ \\
\hline $\begin{array}{l}\text { 22. Ипапа ужасно пережсивал } \\
\text { Ø, что Джерик считает его } \\
\text { предателем (Нусинова). }\end{array}$ & $\begin{array}{l}\text { Eciato al pensiero che Jerik lo } \\
\text { considerasse un traditore. }\end{array}$ \\
\hline
\end{tabular}

Эмоция всегда вторична, она возникает как на основе знаний о том, что произошло, так и предположений о том, что должно или может произойти. Отсюда - тесная связь эмотивов с планом будущего. Cp.:

23. Он радовался $\boldsymbol{\emptyset}$, что до $\mathrm{Si}$ rallegrava pensando che, получения ответа квартиры fino a quando non fosse arriприискивать не понадобится vata la risposta, non avrebbe (Гончаров, НКРЯ). avuto bisogno di cercare un altro appartamento... (Argia Michettoni).

24. Левин... остался доволен Levin... fu contento, penØ тем, что вывезется все, что sando che così sarebbe stato нужно... (Толстой, НКРЯ). doveva... (Luporini).

25. Мне стало стыдно, но я Provai un senso di vergogna, успокоила себя Ø: наверное, ma mi tranquillizzai pensando когда поеду назад, она снова che forse, al ritorno, sarebbe придет к поезду... (Толстая). venuta di nuovo al treno...

Эмотивный модус может редуцироваться в итальянском тексте до прилагательного в атрибутивной функции, уступая место предикату пропозициональной установки ментальной семантики. Ср.:

\begin{tabular}{|lll|l|}
\hline 26. Саша и Мотька... & Sasa e Mot'ka... la guarda-
\end{tabular} смотрели на нее, и им vano felici, pensando che ora было приятно Ø, что она essa aveva rotto il digiuno... оскоромилась... (Чехов, (Malcovati).

НКРЯ).

В зависимости от семантики глагола-эмотива дополнительный модализатор может играть различные роли в семантической структуре высказывания. Так, семантика 'сожаления' в следующих примерах включает ассертивный компонент « $X$ считает (ощущает): Р плохо; отсутствие Р хорошо» [14, с. 84]. Ср.: \begin{tabular}{|l|l|}
\hline $\begin{array}{l}\text { 27. А мне на этот раз жаль } \\
\text { Ø, что Федора нет со мною }\end{array}$ & $\begin{array}{l}\text { pensta volta mi rattrista } \\
\text { (Савинков). }\end{array}$ \\
con me.
\end{tabular}

28. Si rammarciava al pen- Жаль только Ø, что первые siero che i primi due giorni два дня придется потерять avrebbero dovuto perderli per на постройку лачуги. costruire il capanno (Cassola).

Именно элемент 'считает' является здесь тем «мостиком», который связывает эмотивный модус с ментальным. В русском тексте, если Экспериенцер совпадает с говорящим, то он часто не имеет поверхностно-синтаксического выражения в форме дательного падежа. Ср.: Ø Жаль, что Федора нет со мною.

Вместе с тем в конструкциях с эмотивами нет строгой синтаксической зависимости между модусом и пропозицией: не случайно в итальянском тексте употребление сослагательного наклонения в этих конструкциях факультативно. В примерах 28 и 29 оно отсутствует, что, видимо, определяется планом будущего времени, тогда как употребление конъюнктива в примере 30 может быть обусловлено присутствием модального глагола potere в значении 'cnoсобна'. Ср.:

\begin{tabular}{|c|c|}
\hline $\begin{array}{l}\text { 29. Смутился дурак и начал } \\
\text { печалиться Ø о том, как бы } \\
\text { прекратить те неприятные } \\
\text { слухи? (Тургенев). }\end{array}$ & $\begin{array}{l}\text { L'imbecille si turbò e comin- } \\
\text { ciò a rattristarsi, pensando a } \\
\text { come avrebbe potuto por fine a } \\
\text { quelle spiacevoli voci. }\end{array}$ \\
\hline $\begin{array}{l}\text { 30. Мне только противно Ø, } \\
\text { что Лиза после Феди может } \\
\text { так сближаться с чужим } \\
\text { человеком (Толстой). }\end{array}$ & $\begin{array}{l}\text { Mi disgusta soltanto vedere } \\
\text { che Liza, dopo Fedja, possa } \\
\text { essere in intimità con un estra- } \\
\text { neo. }\end{array}$ \\
\hline
\end{tabular}


В следующем итальянском примере прямо указано на эмоциональное состояние субъекта, вызванное определенной причиной, связанной с результатом ментальной операции 'понимания':

31. Е poi, quando alle sette della sera il sole è ancora alto e солнце еще высоко, и ты ti commuovi perché ormai hai радуешься Ø, что пришла capito che è arrivata la prima- весна... vera... (Piccolo).

В итальянском тексте употреблен глагол соттиovere, который имеет более абстрактное значение: «produrre sentimenti di affetto, tenerezza, pietà, dolore e sim., o di agitazione, entusiasmo e sim.» [8, p. 407]. Конкретизация эмоции в русском переводе вполне оправдана, ведь еще Г. Фреге выделял компонент 'считать' в семантическом представлении глагола радоваться [15, с. 365].

При глаголе утешать в возвратной форме (когда объект кореферентен субъекту) часто возникает участник Прием-утешение [13, с. 300], который может быть выражен в русском тексте существительным ментальной семантики с пропозициональным актантом, а в итальянском - герундием:

32. - ...Mi consolo pensando - ...Я утешаю себя мыслью, che, quando si nasce Tonni, c'è что ежели ты уж родился на più dignità di morir sott'acqua свет тунцом, то лучше тебе \begin{tabular}{l|l} 
che sott'olio! (Collodi). & кончить свои дни в воде...
\end{tabular}

В русском тексте существительное может редуцироваться до указательного местоимения тот или вовсе отсутствовать. Ср.:

\begin{tabular}{|c|c|}
\hline $\begin{array}{lll}33 . & \text {...Но } \text { [она] } \text { утешала } \\
\text { себя } & \text { тем, что он честный } \\
\text { человек... (Толстой, НКРЯ). }\end{array}$ & $\begin{array}{l}\text {...Ma si rassicurava pensan- } \\
\text { do che egli era un uomo d'o- } \\
\text { nore... (Luporini). }\end{array}$ \\
\hline $\begin{array}{l}\text { 34. Обломов... утешался } \\
\text { отчасти тем, что деньги эти } \\
\text { пойдут на сирот... (Гонча- } \\
\text { ров, НКРЯ). }\end{array}$ & $\begin{array}{l}\text { Oblomov... si era in parte } \\
\text { consolato pensando che quei } \\
\text { denari sarebbero andati agli } \\
\text { orfani... (Argia Michettoni). }\end{array}$ \\
\hline $\begin{array}{l}35 . . . \text { Так что все больше от } \\
\text { себя сочиняю и только тем и } \\
\text { утешаюсь, что от этого еще } \\
\text { лучше выходит (Достоев- } \\
\text { ский, НКРЯ). }\end{array}$ & $\begin{array}{l}\text {...Sicché, più che altro, in- } \\
\text { vento tutto, e mi consolo solo } \\
\text { pensando che così, forse, vien } \\
\text { meglio (Kraiski). }\end{array}$ \\
\hline $\begin{array}{l}\text { 36. Старики утешают себя } \\
\emptyset, \text { что если теперь нет ни- } \\
\text { чего, то было что-то в со- } \\
\text { роковых или шестидесятых } \\
\text { годах... (Чехов, НКРЯ). }\end{array}$ & $\begin{array}{l}\text { La gente vecchia si consola, } \\
\text { pensando che se non esiste } \\
\text { più ora, è esistito qualche cosa } \\
\text { di simile verso il 1850-1860 } \\
\text { (Malcovati). }\end{array}$ \\
\hline
\end{tabular}

У глагола испугаться при переводе ментальный компонент также выходит на первый план, тогда как эмотивная составляющая подавляется. Ср.:

\begin{tabular}{|l|l|}
\hline 37. Он помнил, однако, & Ricordò tuttavia, in seguito, che \\
как вдруг, выйдя на канаву, & raggiunto il canaletto a un trat- \\
uсnугался Ø, что мало народу & to s'era spaventato, pensando \\
и что тут приметнее... & che con poca gente lo si potesse \\
(Достоевский, НКРЯ). & notare di più... (Kraiski). \\
\hline
\end{tabular}

Характерно, что в итальянском тексте второе из соподчиненных придаточных свернуто в предложный предикативный оборот. Образуется следующая иерархическая конструкция: 'он испугался, что тут приметнее, поскольку народу мало'.

\section{Выводы}

В статье были рассмотрены некоторые итальянские конструкции с глаголами речи и внутреннего эмоционального состояния как глаголами пропозициональной установки, а также их русские эквиваленты. Во многих случаях при присоединении пропозиционального актанта к этим глаголам требуется введения еще одного предиката, который с точки зрения русского языкового сознания может показаться лишним. Были определены контексты употребления таких предикатов, исследована степень их обязательности/факультативности, определены причины их включения в структуру высказывания.

Некоторые глаголы речи, в частности интерпретационные глаголы mentire и insistere, свободно присоединяющие пропозициональный актант в русском языке, лишены такой способности в итальянском.

Предикаты внутреннего состояния всегда имеют в своей семантике эпистемический компонент, который в итальянском тексте имеет тенденцию к экспликации. В целом элементы модуса получают в итальянском тексте более развернутое выражение по сравнению с русским текстом, где наблюдается тенденция к их полной или частичной редукции.

Представляется, что это можно рассматривать как частный случай более общего явления - стремления итальянского языка к максимально высокой степени экспликации модусных элементов высказывания, что позволяет говорить об итальянском тексте как о тексте иерархического типа.

\section{ЛИТЕРАТУРА}

1. Говорухо Р. A. Глаголы речи в русском и итальянском текстах (пропозициональный аспект) // Итальянский язык и культура : связи, контакты, заимствования. Проблемы итальянистики. Вып. 7. М. : РГГУ, 2019. C. $135-160$.

2. Говорухо P. A. Глаголы мысли в итальянском и русском текстах (пропозициональный аспект) // Вестник Моск. ун-та. Серия 9. Филология. 2019. № 6. С. 73-90.

3. Govorukho R. Qualche osservazione sull'uso dei verbi proposizionali in italiano e in russo // L'analisi linguistica e letteraria. XVIII, 2010. Milano. Pp. 187-200.

4. Плунгян В. А. Введение в грамматическую семантику : грамматические значения и грамматические системы языков мира. М. : РГГУ, 2011. 672 с. 
5. Prandi M., De Santis C. Manuale di linguistica e di grammatica italiana. Novara : De Agostini Scuola, 2019. $526 \mathrm{p}$.

6. Арутюнова Н. Д. Типы модусов. Инверсия модуса и пропозиции // Язык и мир человека. М. : Школа «Языки русской культуры», 1999. С. 428-437.

7. Апресян Ю. Д. Исследования по семантике и лексикографии : в 2 т. Т. 1. Парадигматика. М. : Языки славянской культуры, 2009. 568 с.

8. Lo Zingarelli. Vocabolario della lingua italiana. Bologna : Zanichelli, 2017. 2256 p.

9. Blumenthal P., Rovere G. Pons Worterbuch der italienischen Verben : Konstruktionen, Bedeutungen, Ubersetzungen. Stuttgart : Klett, 1998. 1170 p.

10. Garigliano P. Sintassi della lingua italiana. Catagna : C.U.E.C.M., 2002. 1023 p.

11. Апресян Ю. Д. Избранные труды. Т. 2. Интегральное описание языка и системная лексикография. М. : Школа «Языки русской культуры», 1995. 767 с.

12. Кустова Г. А. Типы производных значений и механизмы языкового расширения. М. : Языки славянской культуры, 2004. 472 с.

13. Падучева Е. В. Динамические модели в семантике лексики. М. : Языки славянской культуры, 2004. $608 \mathrm{c}$.

14. Зализняк A. A. О семантике сожаления // Русская семантика в типологической перспективе. М. : Языки славянской культуры, 2013. С. 79-104.

15. Фреге Г. Смысл и денотат // Семиотика и информатика. М. : Языки русской культуры, 1997. С. 351-380.

\section{ИСТОЧНИКИ}

1. Национальный корпус русского языка. URL: http:// www. ruscorpora.ru/new/

2. Акунин Б. Статский советник. М. : Захаров, 2003.Akunin B. Il consigliere di stato. Milano : Frassinelli, 2004 (Trad. di M. Gallenzi).

3. Гаврилов А. История майора Симинькова // Русские цветы зла : сб. / сост. В. Ерофеев. М. : Зебра Е, 2004. C. 350-364. - Fiori del male russi. Antologia. (a cura di Viktor Erofeev). Roma : Voland, 2001. Pp. 205-216 (Trad. di Dinelli M.).

4. Гришковеи Е. Рубашка : роман. М. : Махаон, 2008. - Griskovec E. La camicia. Firenze: Nikita, 2011 (Trad. di C. Napoli).

5. Евтушенко E. Ардабиола // Точка опоры. М., 1981. - Evtusenko E. Ardabiola. Roma : Lucarini, 1991 (Trad. di E. Pacucci).

6. Казаков Ю. Осень в дубовых лесах // Казаков Ю. Во сне ты горько плакал. Рассказы. М. : Современник, 2000. C. 283-297. - Kazakov J. Autunno nei boschi di querce. Genova: Il melangolo, 1991. Pp. 7-42. (Trad. di Fiannacca C.).

7. Нусинова Н. Приключения Джерика. М. : Самокат, 2006. - Nussinova N. Il diritto di amare un cane. Milano : Rizzoli, 2008 (Trad. di C. Balistreri).
8. Пелевин В. Желтая стрела. М. : Эксмо, 2009. Pelevin V. La lanterna blu. Milano : Mondadori, 2002 (Trad. di G. Perugini).

9. Савинков Б. Воспоминания террориста. Конь бледный. Конь вороной. М. : АСТ, 2004. - Savinkov B. Il cavallo pallido. Marsilio, 1993. 167 p. (trad. Di Paola C.).

10. Толстой Л. Живой труп. Il cadavere vivente. На итал. и русск. яз. Venezia : Marsilio, 1991. 199 р. (trad. Leone S.).

11. Толстая Н. Полярные зори. Bagliori polari. На итал. и русск. яз. Disseuco, Università degli Studi di Roma "La Sapienza", 2002. 61 p. (trad. Natalie Malinin).

12. Трифонов Ю. Дом на набережной. М. : Астрель, 2004. C. 8-158. - Trifonov Ju. La casa sul lungofiume. Roma, 1997. 157 p. (trad. Costantini V.).

13. Тургенев И. С. Стихотворения в прозе. Senilia. На итал. и русск. яз. Venezia : Marsilio, 1996. 258 р. (trad. Garzonio S.).

15. Baricco A. Oceano mare. Milano : Rizzoli, 1997. 240 р. - Барикко А. Море-океан. М. : Амфора,1997. 220 с. (пер. Е. Киселёва).

16. Camon F. Un altare per la madre. Milano : Garzanti, 2002. 131 p. - Камон Ф. Алтарь для матери // Итальянская повесть : 70-е годы. М. : Прогресс, 1982. С. 189-249 (пер. М. Архангельской).

17. Campanile A. Agosto, moglie mia non ti conosco. Milano : BUR, 1999. - Кампаниле A. В августе жену знать не желаю. М. : Эксмо, 2004 (пер. Н. Ковалева).

18. Cassola C. Il taglio del bosco. Milano : Mondadori, 1969. - Кассола К. Рубка леса. М. : Издательство иностранной литературы, 1958 (пер. Д. Розенталя, Л. Шаровой).

19. Collodi $C$. Priklučenija Pinocchio. In Italiano e in Russo, na ital'janskom i russkom jazykach. Moskva, 2002 (пер. Э. Казакевича).

20. Lunari L. Tre sull'altalena. Milano : BUR, 1994. Лунари Л. Трое на качелях // Театр. 1993. № 12. С. 159185 (пер. Н. Живаго).

21. Nanetti $A$. Mio nonno era un ciliegio. Torino : Einaudi Ragazzi, 2009. - Нанетти А. Мой дедушка был вишней. М. : Самокат, 2011 (пер. А. Красильщик).

22. Piccolo $F$. Momenti di trascurabile felicità. Torino : Einaudi, 2010. - Пикколо Ф. Минуты будничного счастья. M. : Corpus, 2012 (пер. Е. Солоновича).

\section{REFERENCES}

1. Govorukho R. A. Glagoly rechi v russkom i ital'janskom tekstah (propozicional'nyj aspekt) [Speaking Verbs in Russian and Italian Texts (Propositional Aspect)] // Ital'janskij jazyk i kul'tura: Svjazi, kontakty, zaimstvovanija. Problemy ital'janistiki [Italian Language and Culture: Links, Contacts and Borrowings. Problems in Italian Studies]. Issue 7. Moscow: RGGU, 2019. Pp. 135-160.

2. Govorukho R. A. Glagoly mysli v ital'janskom $i$ russkom tekstah (propozicional'nyj aspekt) [Thinking Verbs in Russian and Italian Texts (Propositional Aspect)] In 
Vestnik Moskovskogo universiteta. Serija 9. Filologija. 2019. No. 6. Pp. 73-90.

3. Govorukho R. A. Qualche osservazione sull'uso dei verbi proposizionali in italiano e in russo // L'analisi linguistica e letteraria. XVIII, 2010. Milano. Pp. 187-200.

4. Plungjan V. A. Vvedenie v grammaticheskuju semantiku: grammaticheskie znachenija i grammaticheskie sistemy jazykov mira [Introduction to Grammatical Semantics: Grammatical Meanings and Grammatical Systems of Languages in the World]. Moscow: RGGU, 2011. 672 p.

5. Prandi M., De Santis C. Manuale di linguistica e di grammatica italiana. Novara : De Agostini Scuola, 2019. $526 \mathrm{p}$.

6. Arutjunova N. D. Tipy modusov. Inversija modusa $i$ propozicii [Modal Types: Modal and Propositional Inversion] // Jazyk i mir cheloveka [Language and World of Man]. Moscow: Shkola «Jazyki russkoj kul’tury», 1999. Pp. 428 437.

7. Apresjan Ju. D. Issledovanija po semantike i leksikografi: $v 2$ tomah. Tom 1. Paradigmatika [Studies in semantics and lexicography in 2 volumes. Vol. 1. Paradimatics] Moscow: Jazyki slavjanskoj kul'tury, 2009. 568 p.

8. Lo Zingarelli. Vocabolario della lingua italiana. Bologna: Zanichelli, 2017. 2256 p.

Российский государственный гуманитарный университет

Говорухо Р. А., кандидат филологических наук, доиент, директор Российско-итальянского учебно-научного иентра

E-mail: govorroman@mail.ru

Поступила в редакцию 24 апреля 2020 г.

Принята к публикачии 15 июня 2020 г.

\section{Для цитирования:}

Говорухо Р. А. Глаголы речи и мысли как средства связи в итальянском тексте // Вестник Воронежского государственного университета. Серия: Лингвистика и межкультурная коммуникация. 2020. № 3. С. 114-121. DOI: https://doi.org/10.17308/lic.2020.3/2941
9. Blumenthal P., Rovere G. Pons Worterbuch der italienischen Verben: Konstruktionen, Bedeutungen, Ubersetzungen. Stuttgart: Klett, 1998. 1170 p.

10. Garigliano P. Sintassi della lingua italiana. Catagna: C.U.E.C.M., 2002. 1023 p.

11. Apresjan Ju. D. Izbrannye trudy. Tom 2. Integral'noe opisanie jazyka i sistemnaja leksikografija [Selected works. Vol. 2 Integral description of language and systematic lexicography]. Moscow: Shkola «Jazyki russkoj kul'tury», 1995. $767 \mathrm{p}$.

12. Kustova G. A. Tipy proizvodnyh znachenij i mehanizmy jazykovogo rasshirenija [Types of Secondary Meanings and Mechanisms of Linguistic Extension]. Moscow: Jazyki slavjanskoj kul'tury, 2004. 472 p.

13. Paducheva E. V. Dinamicheskie modeli v semantike leksiki [Dynamic Models in Lexical Semantics]. Moscow: Jazyki slavjanskoj kul'tury, 2004. 608 p.

14. Zaliznjak A. A. O semantike sozhalenija [On the Semantics of Regret] // Russkaja semantika v tipologicheskoj perspective [Russian Semantics in the Typological Perspective]. Moscow: Jazyki slavjanskoj kul'tury, 2013. Pp. 79-104.

15. Frege G. Smysl i denotat [Meaning and Denotatum] // Semiotika i informatika [Semiotics and Informatics]. Moskva: Jazyki russkoj kul'tury, 1997. Pp. 351-380.

Russian State University for the Humanities

Govorukho R. A., Candidate of Philology, Associate Professor, Director of the Russian-Italian Center

E-mail: govorroman@mail.ru

Received: 24 April 2020

Accepted: 15 June 2020

\section{For citation:}

Govorukho R. A. Verbs of speaking and thinking as linking elements in Italian text. Proceedings of Voronezh State University. Series: Linguistics and Intercultural Communication. 2020. No. 3. Pp. 114-121. DOI: https:// doi.org/10.17308/lic.2020.3/2941 